\title{
Forhalingens retorik
}

\section{Erfaringen affjernhed i Kafkas prosakunst}

\section{Retorikken i Kafkas prosa}

Der har været overraskende få læsninger af Kafkas prosakunst, der tager udgangspunkt i dens karakteristiske udnyttelse af sprogets retoricitet. Blandt undtagelserne er Clayton Koelbs essay fra 1983, "Kafka's Rhetorical Moment", og femte kapitel af Robert Harimans Political Style. The Artistry of Power fra 1995, "A Boarder in One's Own Home: Franz Kafka's Parables of the Bureaucratic Style”. Begge bidrager til en udlægning af den stadige forhaling, der i det følgende søges gjort gældende som en særegen erfaringsform intimt knyttet til læsningens bevægelse gennem Kafkas tekster. Når denne erfarings retoriske mønstre imidlertid ikke i højere grad er blevet diskuteret, kan det skyldes, at en forhalingens retorik netop ikke er tilgængelig for forståelsens almene erfaring, hvormed en mening begribes.

Her er dog ikke tale om en retorik i ordinær forstand, dvs. fremsættelsen af doxa [mening], der søger at overbevise andre om et bestemt perspektiv på verden. Derimod er der tale om retorik i den mere grundlæggende sproglige forstand, som Nietzsche som den første i moderne tid gør opmærksom på: "Sproget er retorisk, for det vil kun at fremføre et doxa, ikke et epistēmē [viden]" (Nietzsche 1989: 22). Hvor en ordinær retorik fremsætter doxa som udtryk for et subjekts perspektiv på verden, en forståelse af verden, som det gennem overbevisende virkemidler forsøger at få andre til at se på samme måde, indtil det virker og accepteres som en sand viden [epistēmē] om verden, en indsigt bragt på begreb, dér er Nietzsches rent sproglige retorik alene en fremsættelse af doxa, der netop ikke gør fordring på at være sand viden. I overensstemmelse med en sådan opfattelse kan Kafkas prosa læses som en systematisk udnyttelse af sprogets retoricitet. En væsentlig konsekvens heraf er, at den virker afsporende på den almene erfaring, der i et sprogligt udtryk forventer at finde doxa, en mening eller holdning, fremsat med henblik på at forfægte en sand indsigt. Det indebærer, at det ene sæt af doxa kan være lige så sandt som det andet, den ene forståelse eller fortolkning lige som god som den næste, hvilket - i tilfældet med Kafkas prosa - efterlader læser med en grundlæggende ambivalens. 
Uden at fremstille sin udlægning af "Kafkas retoriske øjeblik" i samme termer synes det at være en sådan retoricitet, som Koelb under henvisning til Paul de Man gør gældende for "en stor del af Kafkas fiktion" (Koelb 1983: 37). Koelb henviser til de Mans forståelse af retorik som den sproglige situation, der opstår, "ikke med henblik på at overbevise eller i den blotte anvendelse af figurativt sprog, men i konfrontationen mellem to modstridende fortolkningsmuligheder. Med de Mans ord opstår retorik, 'når det ud fra grammatiske eller andre lingvistiske kriterier er umuligt at afgøre udfaldet af striden mellem de to betydninger, der kan være fuldstændigt modstridende. Retorikken suspenderer logikken radikalt og åbner svimlende muligheder for referentielle vildfarelser' [de Man 1988: 37]" (ibid.). Om lidt skal vi vende tilbage til den retoriske suspension af logikken hos Kafka, men det er ud fra denne retoriske kløft eller apori, der opstår mellem stridende og dog ligebyrdige fortolkningsmuligheder, det han betegner som et "retorisk øjeblik", at Koelb udlægger Kafkas fiktion. Han viser, hvordan en sådan retoricitet i Processen, Slottet og flere fortællinger kommer til udtryk i forskellige ambivalente sætninger, der åbner selve det fiktive rum, hvori fiktionen bevæger sig. I den indledende arrestationsscene i Processen er det første, Josef K. hører om sin arrestation, således sætningen: "De må ikke forlade stedet, De er jo arresteret" (Kafka 1981: 9) fremsat af den ene af to vogtere. Koelb kommenterer: "'Sie dürfen nicht weggehen, Sie sind ja verhaftet' [...]. Dette indskudte 'ja' har en besynderlig effekt på den performative status af vogterens erklæring. For at foretage en arrestation ville man normalt ikke sige: 'Sie sind ja verhaftet'; man ville blot sige: 'Sie sind verhaftet.' Hvis en arrestation allerede havde fundet sted, kunne man sige: 'Sie sind ja verhaftet', men så vidt læseren ved, har ingen fundet sted. Arresterer vogteren K.? Det er ikke klart, om han har autoriteten til at gøre dette, og hans 'ja' antyder, at han ikke har" (Koelb 1983: 38). I og med Josef K. ikke problematiserer, men tværtimod accepterer ambivalensen i vogterens erklæring af hans arrestation, tillader han også, at Processen kan få det stærkt ambivalente forløb, der finder sted i resten af romanen, og som læseren overtager. Alle handlinger på det personlige plan og selve handlingsforløbet forbliver uigennemskueligt: "Kafkas retoriske øjeblik indleder en handling, der ikke har nogen bestemmelig oprindelse, intet archē, selv om det måtte have en bestemt (og skræmmende) telos. Det fremkommer ud af et tomrum, et retorisk atopia, men følger derefter en vej af ægte smerte gennem et deprimerende virkeligt univers" (ibid.: 42). Teksten fremsætter forskellige serier af doxa, men på intet tidspunkt lykkes det at fiksere disse i henhold til et epistēmēe, en sikker viden om, hvad der foregår i tekstens univers: Hvem har arresteret Josef K. og hvorfor? Hvorfor kan han ikke trænge frem til loven eller en ansvarlig autoritet? Hvorfor forværrer han gradvist sin situation, indtil han til sidst skal henrettes?

Robert Hariman læser også Kafka retorisk, men han henholder sig hovedsageligt til det stilistiske udtryk uden at diskutere, hvilke retoriske mønstre og motiver der fremkalder stilen. Han koncentrerer sig om Slottet, men fremlæser en generel bestræbelse på detaljeret at udforske de kommunikative forhold, der er forbundet med en bureaukratisk fremstillingsform, og hvordan et dagligdags liv kan udfolde sig inden for bureaukratiske kulturer. Snarere end at betragte bureaukratiet som genstand for kritik hos Kafka, mener Hariman dog, at man ved at "identificere ele- 
menter af den politiske handlings bureaukratiske stil - dvs. det sæt af kommunikative konventioner der er særegent konstituerende for en kontorkultur - måske kan lære, hvad der for altid undveg Kafkas K.: en viden om hvordan man lever godt i en bureaukratisk verden" (Hariman 1995: 141f.). På den baggrund bliver konklusionen også en smule skuffende vedrørende de mulige handlinger, som et bureaukratis formelle restriktioner tillader, idet Hariman antager, at bureaukratiets vilkår ikke står til at ændre, og det derfor drejer sig om at "bevæge sig mod et bedre liv" inden for dets rammer (ibid.: 176). Hariman læser således Kafka som en opfordring til at handle inden for det politiske spektrum, bureaukratiet sætter, men han undlader desværre at underkaste handlingen som litterært og retorisk fænomen i Kafkas prosa en grundigere analyse. K. fremstår således i denne udlægning alene som en handlingslammet figur, og i fraværet af reelle handlinger bevæger han sig forgæves rundt $\mathrm{i}$ en verden, der på alle niveauer er dybt præget af ambivalens.

Der er imidlertid en anden og mere grundlæggende retorik på spil i Kafkas prosakunst, som ikke tidligere har været behandlet, og som kan anvendes som forklaringsmodel for den ambivalens på handlingsniveauet, som Koelb identificerer, og hvoraf Hariman fremlæser de stilistiske symptomer på bureaukrati. Det er selve forhalingens retorik, der bestandig lægger sig hindrende i vejen for enhver handling; den handling som Hariman til gengæld afkræver mennesket i en bureaukratisk kultur. Og når Kafkas prosa ikke fungerer inden for rammerne af en handlingens retorik, men tværtimod som en forhaling af handling, skyldes det, at prosaen i "det retoriske øjeblik", hvor en konstitutiv ambivalens leder læsningen i forskellige modstridende retninger, opløser handlingens gestus i tøvende bevægelser uden sans for nogen bestemt retning. Kafkas prosakunst lader sig simpelthen læse som en udforskning af væsensforskellen mellem handlinger og bevægelser.

Handlinger er motiverede, dog uden at motivet nødvendigvis behøver at være gjort bevidst eller overvejet fra den handlendes side, men de udføres rettet mod et mål, med et formål for øje. Det er formålet, der motiverer handlingen og bringer den til udførelse. Dette er netop den afgørende forskel mellem bevægelser og handlinger: Isoleret betragtet er bevægelser ikke rettet mod noget mål, bevægelser bevæger sig selv som ren forandring, formålsløst gentagende sig selv. I den forstand er bevægelser rent fysiske processer (cf. sofismens begreb om physis). En handling er sammensat af bevægelser, men disse gennemføres underordnet et motiv, de koordineres med et formål for øje og fremstår under en lovmæssigheds herredømme (cf. sofismens begreb om nomos). I forbindelse med sin analyse af det, hun kalder "Vita Activa i den moderne tidsalder", henviser Hannah Arendt kort til Kafka i slutningen af sit hovedværk, The Human Condition (1958). Her anlægger hun det arkimediske punkt, at hvis "mennesket og alle dets aktiviteter betragtes fra et tilstrækkelig fjernt udsigtspunkt i universet, ville de ikke fremtræde som aktiviteter af nogen art, men som processer" (Arendt 1958: 322). Det er sådanne processer af rene bevægelser uden noget orienterende motiv, der står tilbage at læse i Kafkas prosa, når forhalingens retorik udsætter handlingen eller forhindrer, at den kommer til udførelse.

Den amerikanske retoriker og litterat Kenneth Burke har givet forskellige bestemmelser af denne forskel mellem bevægelse og handling, både forstået ontologisk og som litterært og retorisk fænomen. I Grammar of Motives (1945) giver han 
den grundlæggende definition, som han udvikler i senere værker, og han bestemmer handling ("action") som det, der konstituerer mennesket, og bevægelse ("motion") som handlingens dialektiske modpol, der alene fremkaldes af fysiske kræfters gensidige påvirkning ("sheer locomotion", Burke 1969b: 85) (jf. Grammar of Motives, passim, særligt pp. 135ff.). Der er dog ikke tale om nogen simpel dialektik mellem bevægelse og handling i Burkes ontologi, og han er egentlig kun interesseret i bevægelser, for så vidt de i sammenhæng med handlinger kan virke forklarende i forhold til motiver, der har hans primære interesse. Motiver har ingen direkte, materiel fremtrædelse, men styrer eller orienterer handlinger. I sig selv ligger motivet et sted mellem bevægelse og handling og kommer i stand, så snart bevægelser bringes til at udføre handlinger. Omvendt kan handlinger opløses i bevægelser fx i form af tøven eller nølen, der afbryder en handling, gør den ubeslutsom, umotiveret. I forlængelse heraf opfatter Burke sprog som symbolsk handling, og han udvikler en strategi, der, gennem en analyse af sprogligt udtrykte handlinger i deres relation til scene, aktører, midler og formål, søger at fremlæse det uudtalte motiv, der ligger til grund for dem. Det er i den forstand, at hans grammatik over motiver kan give anledning til det, han med titlen på et senere værk betegner som A Rhetoric of Motives (1950). I sig selv er handlinger symbolske og for så vidt også retoriske, hvorimod bevægelser i sig selv er "ikke-symbolske", som han udtrykker det i essayet "(Nonsymbolic) Motion/(Symbolic) Action". Men den grundlæggende retoricitet i handlingen korresponderer i sin forståelse af sproget som symbolsk handling med Nietzsches forståelse af sproget som retorisk.

Med udgangspunkt i sådanne termer lader forhalingens retorik sig læse hos Kafka alle de steder, hvor sproget fremskriver handlinger i færd med at opløse sig i bevægelser. I kraft af at der i sagens natur er tale om sprog, bibeholder bevægelserne altid et skin af handling, og for så vidt vil de endnu forekomme tilsyneladende motiverede, ja faktisk kan de fremstå som besat af et eneste motiv: Begæret efter at trænge ind i selve motivets mysterium, at stå frem foran den almene lovmæssighed der styrer enhver handling og forlener den med et formål. Sådan læser Burke det da også: "Kafka er, om man vil, 'religiøs' i sin optagethed af det ultimative mysterium, det universelle fundament for menneskelige motiver" (Burke 1969b: 234). Men han åbner også op for, at denne rettethed i prosaen mod et universelt motiv kan læses som i bevægelse mod opløsning, nemlig en opløsning i latter, idet han fortsætter: "Men hans redegørelse for det religiøse motiv er 'humoristisk" (ibid.). Og videre: "I Slottet er latteren og uddannelsens sociale retorik (to former for 'ren overtalelse' på denne side af det religiøse) ikke et emne, der diskuteres, men det udgør snarere selve værkets væsen. Latteren er, i sin groteske modifikation, indlejret i selve bogens udformning og metode, den sært 'humoristiske' behandling af ærbødighed" (ibid.: 240). Også Processen ville kunne læses, som om alle Josef K.s handlinger havde det ene mål at trænge ind i "det ultimative mysterium”, og hver handling skulle da være en vej til målet. Alle handlinger, der synes udført med en nærmest overdreven forpligtelse, pertentlighed eller omstændelighed, ville da udelukkende have det sigte at virkeliggøre det ene formål, der motiverer dem. Men læst således overser man, at handlingerne undervejs, på vejen til målet, diffunderer og opløser sig i sporadiske bevægelser. De synes at miste deres telos, deres rettethed eller formålsbestemthed, 
ingen handling viser tilsyneladende den rette vej, og den tilbageværende række af disparate, forgæves bevægelser leder ikke frem til nogen udvej. "Der gives et mål, men ingen vej; men det vi kalder en vej er nølen", som Kafka siger i en af sine mest kendte aforismer ("Betrachtungen über Sünde, Leid, Hoffnung und den wahren Weg", nr. 26).

Generelt kan man sige, at i Kafkas fortællinger, i manglen på motiv som orienteringspunkt, fortaber alle gestus handlingens almene struktur, og personerne efterlades i en vildfaren, fortvivlet eller aberrativ situation. Dette kommer fx tydeligt til udtryk i den korte "En kommentar" fra 1922, en af de efterladte fortællinger, her i Per Øhrgaards oversættelse:

4 Det var meget tidligt om morgenen, gaderne rene og tomme, jeg gik til banegården. Da jeg sammenlignede et tårnur med mit eget ur, så jeg at det allerede var meget senere end jeg havde troet, jeg måtte skynde mig meget, skrækken over denne opdagelse fik mig til at tvivle på den rette vej, jeg var endnu ikke særlig godt kendt med denne by, heldigvis var en politibetjent i nærheden, jeg løb hen til ham og spurgte ham åndeløs om vej. Han smilede og sagde: "Mig vil du have til at vise dig vej?" "Ja," sagde jeg, "da jeg ikke selv kan finde den." "Opgiv det, opgiv det," sagde han og vendte sig bort i et stort sving, som folk gør der vil være alene med deres latter (Kafka 2008a: 355).

Jeget efterlades her i en nødstedt situation, der i fiktionens univers er fastholdt midt imellem et aldrig artikuleret og dermed ukendt oprindelsessted (et hotel?) og det, der tilsyneladende er et urealiserbart mål (banegården). Der opstår da det, som Koelb kalder et retorisk øjeblik: her er "intet archē, selv om det måtte have en bestemt [...] telos". Der anvises ingen udvej, selv fra den i situationen mest kyndige autoritet, politibetjenten, er der ingen hjælp at hente. "Der gives et mål, men ingen vej”, som Kafka siger, og målet er endda klart, omend rudimentært fremstillet som et motiv med den handling, jeget indledningsvis kaster sig ud i: "jeg gik til banegården". Banegården er midlet til videre handlinger, herfra kan jeget bevæge sig videre ud i verden, mod nye opgaver, nye mål, også selv hvis målet eventuelt blot skulle være hjemmets fortrolighed. Motivet for hans handling er ydermere accentueret af travlhed, situationen er skildret som presserende, men jeget efterlades i fortællingen, ikke på vej mod målet, men på vejen, som i realiteten altså blot er en "nølen". Hele fortællingen udfolder sig på denne måde inden for, med Koelbs udtryk, "et tomrum, et retorisk atopia", handlingerne diffunderer til umotiverede bevægelser: Jegets hastige gang gennem den tomme by, den standsede bevægelse foran betjenten, der burde have kunnet befordre en videre bevægelse og sikret dens handlingsorienterede formål og betjentens eget store sving bort, der efterlader antydningen af en latter. Optrinnet udspiller sig tidligt om morgenen, dagen er endnu ikke præget af andre handlinger eller indtryk, gaderne er rene og tomme, og scenen er på alle måder ryddet for disse bevægelsers stille retorik.

En næsten identisk scene genfindes i "I denne by ..." fra 1920, hvor "det hele tiden [er] tidlig", hvor "gaderne er tomme, rene og stille", og hvor der er helt mennesketomt og derfor ingen handlinger, kun små bevægelser af et vindue, et stykke stof, et gardin og "ellers er der ingen bevægelser" (Kafka 2008a: 254). I "En kommentar" 
fremkommer et sådant scenario af rene bevægelser imidlertid gennem en gradvis reduktion af handlingerne og deres motiv. Der finder en automatisering eller mekanisering af handlingernes almene struktur sted med mindelser om den slapstick, man kan se fremstillet i Charlie Chaplin eller Buster Keatons stumfilm fra samme periode. Og når den tilstræbte handling opløses i ufrivillige, rent kropslige bevægelser, efterlades beskueren med en latter, som den betjenten i fortællingen giver læseren mulighed for at sympatisere eller identificere sig med. Den lattervækkende effekt lader sig yderliger belyse i termer fra Henri Bergsons æstetik, sådan som den fremstilles i Latteren. Her viser Bergson netop, hvordan "det latterlige" fremkommer i form af "meningsløse bevægelser" som resultat af en "vis mekanisk stivhed i situationer, hvor man havde forventet at møde et levende, opmærksomt, smidigt og fleksibelt menneske" (20). Ligesom hos Kafka bliver reduktionen af handlingerne, der hører til det menneskelige liv, hos Bergson til en "gestikulationernes og bevægelsernes komik", og han fremsætter på den baggrund følgende bestemmelse, der netop synes karakteristisk for Kafkas prosa: "Det menneskelige legemes stillinger, gestikulationer og bevægelser er latterlige i præcis det omfang som dette legeme får os til at tænke på simpel mekanik" (32).

Situationen skildret i "En kommentar" er ganske typisk for Kafka, og en række af de træk, der her optræder i sammentrængt form, kan genfindes overalt i hans prosakunst, men gerne udpenslet i en detailstudie i de helt korte fortællinger. I åbningen af "Tornebusken", også en efterladt fortælling fra samme år, er en mand på spadseretur i en offentlig park endt i en "uigennemtrængelig tornebusk" uden tilsyneladende mulighed for at komme ud igen. Under samtale med en parkbetjent bliver det klart, at ingen redning er umiddelbart, ej heller på sigt, forestående, fordi denne, som han siger, først skal "hente nogle arbejdere der kan hugge vejen fri, og inden da også indhente tilladelse fra hr. parkdirektøren" (Kafka 2008a: 306). Heller ikke her er der altså nogen hjælp at hente hos de autoriteter, der burde være forsynet med den fornødne myndighed til at afhjælpe situationen. På intet tidspunkt meddeles, hvor han kom fra, hvad hans mål var, eller hvordan han havde forvildet sig ind i busken, og inden for fortællingens rammer forbliver manden fanget i den fortvivlede situation.

I en anden af de efterladte fortællinger, "Byen ligner solen" fra 1920, er alt lys samlet i midten: "det blænder, man forvilder sig, man kan ikke finde gaderne, husene, man kommer, når man først er trådt ind, formentlig ikke fremad længere" (ibid.: 253). Også her fortoner fortællingens motiv sig, og enhver handling synes på forhånd $\mathrm{d} ø \mathrm{mt}$ til at ende i en vildfarelse og opløses i umotiverede bevægelser. I "Sandheden om Sancho Pansa", hvor hierarkiet mellem Sancho og Don Quixote er vendt på hovedet i forhold til Cervantes roman, "udfører" Quixote "uden fast holdepunkt [...] de mest vanvittige handlinger, der imidlertid, i mangel af deres forudbestemte genstand, som jo netop skulle have været Sancho Pansa, ikke skadede nogen" (ibid.: 232). I denne korte fortælling er Quixotes handlinger på sine mange togter reduceret til at give "Sancho Pansa, en fri mand, [...] stor og nyttig fornøjelse". Lidt på samme måde, som latteren fungerer i "En kommentar", sættes læseren gennem en identifikation med Sancho Pansa også her i stand til at realisere den lattervækkende effekt, der fremkaldes såvel gennem reduktionen af Quixotes 
handlinger til det "vanvittige", og dermed umotiverede, som gennem omvendingen af hierarkiet mellem Sancho Pansa og Quixote. Men ved på denne måde at forhale et motiv for handlingen i dens fiktive univers, reducerer, eller tilnærmer, fortællingen den for læseren til en ren bevægelse. Den retoriske effekt af forhaling er simpelthen denne handlingens bliven bevægelse.

\section{Erfaringen af fjernhed}

I A Rhetoric of Motives påviser Kenneth Burke, at der til grund for retorikkens traditionelle persuasio-princip ligger et identifikationsprincip, som burde danne udgangspunkt for en mere præcis beskrivelse af den retoriske proces (cf. Burke 1969b: 49ff.). Han betragter retoriske motiver som en formel omstændighed, der følger naturligt af sprogets funktioner, og beskriver, hvordan tilhørere til en tale eller læsere af en tekst kan bringes til at identificere sig med diskursens grundlæggende motiv, som dermed kan fremkalde en handling hos dem. Det væsentlige for os i denne sammenhæng er, at Burke ikke sætter tilhøreren eller læseren, diskursens publikum, som et transcendentalt subjekt, der går forud for diskursen, men at han betragter publikum som en indskrevet deltager i den diskurs, som det i retorisk forstand kan lade sig overbevise af. Publikum kan altså betragtes som konstitueret af diskursen. Persuasio er derimod et princip, der netop indebærer et transcendentalt, autonomt subjekt, som det står frit at lade sig overbevise, hvilket for den retoriske teori er problematisk, fordi det herved er forudsat, at publikum i logisk og empirisk forstand går forud for diskursen og eksisterer som selvidentiske individer, med en selvstændig dømmekraft, egne interesser, fordomme og motiver som givne, og dermed uafhængige af den retoriske proces. Den traditionelle retoriks opfattelse af persuasio forudsætter altså et publikum, hvis identitet, værdier og hele ideologiske indstilling er konstitueret forud for diskursen, men det betyder, at den retoriske teori ikke kan redegøre for det publikum, som en diskurs henvender sig til. Derfor fremsætter Burke teorien om identifikation som et princip, der går forud for persuasio, og som gennem en redegørelse for publikum som konstitueret i og med diskursen kan forklare, hvorfor et publikum kan lade sig overbevise af en given diskurs. Identifikation er simpelthen betingelsen for at overbevise: "Man overbeviser kun et menneske, for så vidt man kan udtrykke sig i hans sprog gennem tale, gestus, tonalitet, orden, billede, attitude, forestilling, idet man identificerer sine måder med hans" (ibid.: 55). Alene ved, gennem identifikation, at oversætte sine egne motiver til publikums holdninger kommer en overbevisende og virkningsfuld effekt i stand, men det forudsætter, at publikums holdninger kommer til udtryk gennem diskursen, og at publikum dermed kan siges at være konstitueret i og med diskursen. Det publikum, der reagerer positivt og bekræftende på en persuasiv diskurs, er med andre ord det publikum, der i forvejen er indskrevet i eller konstitueret af diskursen.

Denne retoriske forståelse af publikum som konstitueret af diskursen er generelt anvendelig i forhold til litterære tekster, men afsætter en særlig erfaring hos læseren konstitueret af Kafkas prosa. I første omgang har vi set, hvordan Kafkas tekster reducerer handlingerne i fortællingerne, der ellers ville stå i et symbolsk afbildende forhold til en virkelighed uden for teksterne, til bevægelser, der skaber deres egen 
realitet, et råderum, en mulighed uden for det reelle. Men i næste omgang fremstår læseren som konstitueret af teksterne gennem en proces af identifikation, idet læseren hensættes til "det retoriske øjeblik" af ambivalens, hvor forståelsen støder ind i den apori ikke at kunne underordne de reducerede handlingers bevægelse under et samlende motiv. I bestræbelsen på at bringe Kafkas tekst på begreb iværksætter og gentager læserens bevægelser gennem teksten samtidig tekstens egne bevægelser. Men hvis teksten læses således, virkeliggør læsningen også den identifikation, hvormed læseren er konstitueret af teksten. Forhalingens retorik, der bestandig holder motivet $i$ ave, åbner hermed for en særegen litterær erfaring, hvis særegenhed beror på, at den tilhører den konstituerede læser i fiktionens mulige univers og ikke angår en virkelighed uden for, forud for eller uafhængigt af teksten.

Kafkas prosa kan generelt læses som en udnyttelse af en sådan forhalingens retorik, der giver anledning til en særegen litterær erfaring uden for den reelle verdens mening og logik. Hvis vi tager Processen som eksempel, fremgår det af slutningen, hvordan alle tilløb til at underordne romanens handlinger et samlende og forklarende motiv opløses i den absurde situation af den afsluttende og øjensynligt bydende nødvendige handling: K.s henrettelse. Umiddelbart før Josef K. henrettes af to lakajer for det bizarre retsmaskineri, der gennem hele romanen har drevet hovedpersonen rundt i sin ubønhørlige og uigennemsigtige logik, skriver Kafka: "Logikken er ganske vist urokkelig, men den står ikke imod et menneske, der vil leve" (Kafka 1981: 243). K. har altså ladet sit liv reducere til at forsøge at forstå logikken i den ret, der i Lovens navn, desuagtet hans angiveligt retskafne væsen, har indledt sag mod ham, men på trods af sin ildhu må han lide den tort at "træde af som et menneske, der intet forstår" (240). Nu har der ganske vist været rejst tvivl om kapitlernes rette orden i Kafkas ufuldstændige roman, hvis manuskript han i sit litterære testamente til den for så vidt lykkeligt svigefulde ven Max Brod fordrede brændt. Det er altså ikke givet, at Josef K. skulle have været henrettet, måske passagen, som adskillige andre, siden ville være blevet strøget, for Kafka så helst romanen uafsluttet og fortsat eller forhalet i en form for uendelighed. Gennem det posthume arrangement af kapitlerne, hvor K.s død bliver sammenfaldende med romanens slutning, forstærkes imidlertid læserens lyst til at finde et motiv for denne handling, der fremstår som absurd: plaget af en øjensynligt ubegrundet skyldfølelse synes K. til sidst at acceptere konsekvensen af en ukendt Lov, som han forbliver ude af stand til at konfrontere, og logikken sikrer aldrig livet en forsonende meningsfuldhed.

Uanset om det absurde i denne konsekvens udlægges religiøst, eksistentielt, psykologisk, sociologisk, historisk eller alment kritisk, synes sådanne fortolkningsperspektiver, der dominerer kommentarlitteraturen, imidlertid at overse den særlige litterære erfaring i sammenhængen. I forståelsen af Processen og dens anvendelse af forhalingens retorik drejer det sig netop om ikke at uddrage et bestemt budskab, men snarere om at læse dens bevægelser, inventar, mønstre, rammer og indbyrdes sammenhænge, dvs. selve tekstens fysik og ikke dens almenmenneskelige udsagn. Det afsluttende kapitel er én lang farceagtig opløsning af alle handlinger i mekaniske, komiske bevægelser fra den besynderlige gangart, der beskrives med Josef K. modstræbende fastholdt mellem de to vogtere, til den akavede stilling, $\mathrm{K}$. bringes $\mathrm{i}$ inden henrettelsen, og den uafklarede udveksling af kniven mellem de to vogtere. 


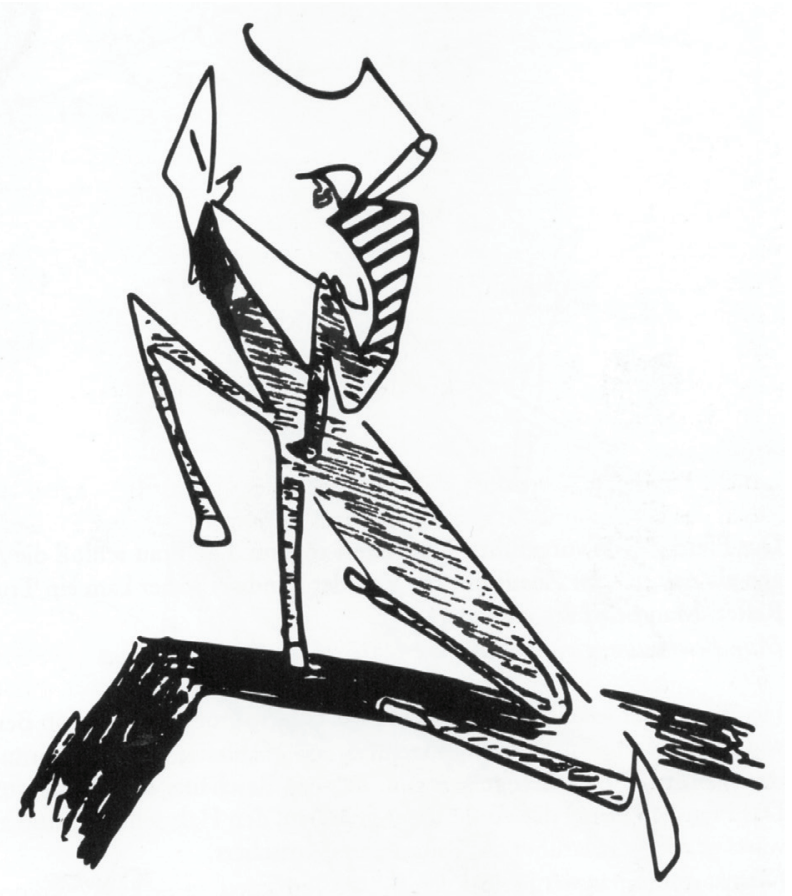

Den afsluttende scene har installeret en person med opstrakte hænder i et vindue i en fjern bygning. Denne persons blik på optrinnet fra det fjerne konstituerer et muligt identifikationspunkt for læseren, der på afstand betragter "mennesket og alle dets aktiviteter", som Hanne Arendt taler om, fra et punkt, hvor de ikke længere giver mening, og hvor de er blevet til rene bevægelser. Den konstituerede læser i Processen er underlagt denne litterært betingede erfaring af meningsløshed.

For den empiriske læser af Kafka bliver det i næste omgang et spørgsmål om at bringe sig i forhold til den konstituerede læser ud fra overvejelsen om, hvordan man kan realisere hans mulige erfaringer. Det drejer sig nu om at vise, hvordan litteraturens mulige erfaringsrum væver sig ind i læserens virkelige erfaringer. Litterær erfaring kan her ikke længere opfattes som udtryk for en indbildningskraft, der med fiktionens muligheder andenhånds bearbejder virkelige erfaringer, dvs. "oversætter" virkeligheden til litteratur, sådan som det ville være tilfældet i den fortolkning, der konstruerer et motiv for romanens handlinger. Kafkas prosakunst er dog heller ikke udtryk for det rene spilfægteri afsondret fra virkelige erfaringer, derimod hænger de mulige erfaringer, som den prøvende leger med, tæt sammen med erfaringens generelle betingelser, også hvor de angår den virkelighed, hvori vi danner vores almene erfaringer. Den kan derfor læses som en udnyttelse af et særligt erfaringsrum, hvor det virkelige og det mulige i sammenhæng udgør en eksperimenterende undersøgelse af erfaringens generelle betingelser. Kort kan man ud fra dens retoriske anlæg som forhaling bestemme den konstituerede læsers erfaring i Kafkas prosa som en erfaring af det fjerne, og i det følgende vil vi forsøge at forstå de fremlæste retoriske vilkår i termer af erfaring.

I første omgang viser erfaringen af det fjerne sig i teksternes systematiske afsøgning af et fjernt mål, som hovedpersonen i sagens natur ikke kan gøre nærværende andet end gennem tilnærmelser, for der findes jo intet virkeligt nærvær med det 
fjerne, der da ville ophøre med at være fjernt og i stedet være nært. Alt, hvad Kafkas pen beskrivende søger at tilnærme sig, fastholdes i det fjerne, og hver beskrivelse øger blot afstanden, fordi den straks afsætter nye forhindringer på vejen mod det fjerne. Vejen mod målet bliver, som Kafka samstemmende med taoismen siger, selv målet. Traditionelt har det vestlige begreb om erfaring stået i forbindelse med tilliden til et nærvær, drømmen om at bebo målet, uden at forbindelsen mellem erfaringens vej til målet og målet selv nødvendigvis har været gjort bevidst. Men Kafka arbejder i sin prosa med et anderledes erfaringsbegreb, der tager udgangspunkt i fjernheden som vilkår.

En ganske kort fortælling, der klart fremskriver denne erfaring, er "Den nærmeste landsby" fra novellesamlingen En landlæge (1919):

64 Min bedstefar plejede at sige: 'Livet er forbavsende kort. Nu i erindringen trækker det sig sådan sammen for mig at jeg for eksempel har svært ved at begribe hvordan et ungt menneske kan beslutte sig til at ride til den nærmeste landsby, uden at frygte at der - helt bortset fra ulykkelige tilskikkelser - selv i et almindeligt, lykkeligt livsforløb langtfra er tid nok til et sådant ridt' (Kafka 2008b: 174)

Bedstefaderen gør her rede for sit livs erfaring, der med litteraturens mulighed for at hævde det umulige sammentrænges i et enkelt punkt: frygten for at livets korthed er for lille til at tilbagelægge selv den korteste afstand. Fortællingens imaginære rum forkortes ganske vist voldsomt, men selve fortællingen fastholder den nærmeste landsby i en fjernhed. Det tilsyneladende absurde i fortællingens leg med en mulig erfaring, der synes at måtte betvivles af vores virkelige erfaringer, forsvinder, hvis man forstår det virkelige i al almindelighed som en eliminering af det mulige og accepterer, at fortællekunstens uendelige muligheder har deres egen virkelighed. Den almene virkelighed vil endda være mindre virkelig end fortællingens virkelighed, for så vidt som det almene beror på en udelukkelse af fortællingens mange muligheder. Det er i fortællingens egen virkelighed, at forhalingens retorik kan udspille sig, og det er på den baggrund vi kan forstå det skuffende ved Harimans læsning af den bureaukratiske stil hos Kafka, der udlægges som et billede af en virkelig erfaring uden blik for den retoriske bearbejdning, der finder sted, når erfaringen af det virkelige gennem skriften bliver til fortællingens mulige erfaring.

Så længe vi bevæger os i det mulige, sådan som Kafka gør det i sine prosaeksperimenter, vil vi egentlig ikke kunne nå fra ét punkt til et andet som i det almenes mindre virkelighed: Akilleus indhenter aldrig skildpadden; K. når aldrig frem til Loven eller Dommeren, retsmaskineriets højeste instans; det kejserlige budskab når i fortællingen af samme navn aldrig fra kejseren frem til den enkelte; K. trænger i Slottet aldrig ind i greveslottet. De helt korte fortællinger er ofte eksemplariske med hensyn til at fremstille denne erfarings retoriske betingelser, men de giver desuden anledning til en generel erfaring vedrørende fjernhed. Dette er litteraturens mulige erfaring i undersøgelsen af det fjerne: bestandigt at henvise os til et sted udenfor. Erfaringen af det fjerne er altså, at det i selve sin egenskab af fjernhed er underlagt en principiel afstand, der aldrig kan overvindes. I den virkelige verden undersøger vi derimod det fjerne ved at destruere fænomenet fjernhed: vi sætter fod på månen, 
vi opløser atomerne, vi rejser ud til fjerne lande. Vi vil hele tiden besidde det fjernes eksotik, gøre det nærværende, gøre os virkelige erfaringer med det, men overser da, at man ikke både kan betragte og bade i en regnbues lys.

Det er karakteristisk hos Kafka, at denne litterære erfaring ofte kommer til udtryk som en bevægelse gennem et landskab, en by eller et interiør. Grundbetydningen af erfaring er netop at befare, at gennemvandre, og i Slottet er K. da også landmåler: han opmåler med sine tilnærmelser til det fjerne slot det, der er blevet kaldt "forhindringernes topografi" (Deleuze og Guattari 1982: 61). Når det er en geografisk afstand, der tematiserer fjernheden, bliver det tydeligt, hvordan Kafka i realiteten beskriver en moderne Odyssé. Men i modsætning til Odysseus, der trods alt når hjem til Penelope, er K.s rejse fastholdt i en stadig digression, afvigelser der slår igennem helt ned i selve sprogets omstændelige fremfærd. Det er klart, at den jurakyndige Kafka i jugendtidens Prag må have følt sig besnæret af en tysk kancellistil med dens slyngede syntaks. Modsat Harimans vurdering af K.s forhold til den bureaukratiske stil, kan man roligt sige, at Kafka tilsyneladende befinder sig godt med det sprog, der er underlagt forhalingens retorik og fremstiller en forhindringernes topografi. Jean Starobinski har givet denne topografi en præcis bestemmelse som landskaber og interiører, der frembringes, uden at synet dirigeres direkte hen imod dem, uden at de beskrives, men som ikke desto mindre skaber de forhindringer, som fortællingernes protagonist aldrig vil kunne krydse. Således er ifølge Starobinski især arkitektoniske elementer karakteristiske i form af tærskler eller intervaller mellem objekter og personer, hvor fraværende kræfter hersker og derfor ikke kan overskrides. Han skriver i den forbindelse: "Forhindringen har en dobbelt betydning. Det drejer sig snart om at figurere en verden, som man ikke kan komme ud fra, snart en verden, som man ikke kan komme ind i. Disse to umuligheder falder sammen" (Starobinski 1947: 24).

På alle niveauer søger Kafka således at gøre sig erfaringer med det fjerne, hvilket markerer sig i fortællestilens besynderlige fremmedhed og mangel på individualitet. Den fortællende stemme virker hos Kafka helt blottet for personlighed, modsat fx den Goethe eller Andersen han beundrede, hvor stemmen er langt mere intimt forbundet med forfatteren. Faktisk er denne nærmest neutrale stemme hos Kafka uden fortilfælde. De store prosaister han læste, her også Kierkegaard, Dostojevskij og Flaubert, søgte måske nok, alle forskelle ufortalte, at skabe en lidenskabelig distance til det beskrevne, gennem pseudonymitet, psykologisk indsigt eller æsteticering, men Kafka går et skridt videre. Kafka søger i mere radikal forstand at bringe sig på afstand af den afstand, som hans hovedperson oplever i tilnærmelsen til det fjerne. Den konstituerede læser får herved en intens oplevelse af, hvordan sprog aldrig rammer plet, at det ikke kan bringe verden nærmere et nærvær. I stedet bliver det for læseren et spørgsmål om at skabe sig en erfaring med selve det at fortælle, men som ikke selv kan fortælles. Erfaringen af at fortælle om erfaringerne med det fjerne skaber - med en lille sofisme - en distance til distancen, og det er alene i dette fjerne eksil, at fjernhedens fænomen toner frem, men ak! kun som forsvinding. Dette er den fornemmelse, man kan opleve ved at læse Kafka: det er som om, substansen hele tiden smutter fra én, og man sidder tilbage med en frustreret mistanke om, at man er gået glip af noget. Det er man også, for der var ikke noget at gribe fat i. 
Denne retorisk betingede erfaring af forhaling beskrives i mere ontologisk forpligtede termer af Maurice Blanchot, der i sit essayistiske forfatterskab har udviklet en litteraturfilosofi delvis gennem en bearbejdning af netop Kafkas prosakunst. I fragmentsamlingen Le pas au-delà fra 1973 udtrykker Blanchot det på følgende måde:

4 At nærme sig frembringer forhalingens spil. Spillet med det fjerne og det nære er det fjernes spil. At nærme sig de fjerne ting er et udtryk, der søger at bringe de fjerne ting for dagen og i forbindelse med et nærvær, hvis særlige karakter altså er at være fjern, hvilket det på en måde altid er; således ville nærværet og det fjerne på ny være forbundne dele: et fjernt nærvær, fjernt fra et nærvær, de fjerne ting vil være nærværende derude i det fjerne. Alene det nære vil altså være beskyttet mod besmittelsen fra et nærvær. At være nær er det samme som ikke at være nærværende. Det nære lover det, det aldrig holder. En lovprisning i nærheden af det, der undviger: den nært forestående død, den nært forestående døds fjernhed (Blanchot 1973: 99).

Gennem et sådant spil med det fjerne fremskriver Kafka et klart brud med den dannelsesroman, der har været dominerende i vor forståelse af romankunsten. Protagonisten når hos ham aldrig hjem, men lever og dør ude i bestræbelsen på at forstå det fremmede, ikke for at vende kvalificeret hjem til det kendte, men for at skabe betingelserne for at forstå, at enhver erfaring måske er underlagt det fjernes princip, og at vi for altid er henvist til opbrud uden mulighed for at nå frem til det fjerne, derude, længere væk end længst væk. Det er denne tilstand af "væk" som et mål i sig selv, der kommer til udtryk i den korte, efterladte fortælling fra 1921, "Opbruddet":

Uf Jeg befalede at min hest skulle hentes frem af stalden. Tjeneren forstod mig ikke. Jeg gik selv ud i stalden, sadlede min hest og besteg den. I det fjerne hørte jeg lyden af en trompet, jeg spurgte ham hvad det betød. Han vidste ingenting og havde ingenting hørt. Ved porten standsede han mig og spurgte: "Hvor rider du hen, herre?" "Jeg ved det ikke," sagde jeg, "blot væk herfra, blot væk herfra. Hele tiden væk herfra, kun sådan kan jeg nå mit mål." "Du kender altså dit mål," spurgte han. "Ja," svarede jeg, "det sagde jeg jo. "Væk herfra', det er mit mål." "Du har ingen proviant med," sagde han. "Jeg behøver intet," sagde jeg, "rejsen er så lang at jeg må dø af sult, hvis jeg ikke får noget på vejen. Ingen proviant kan redde mig. Det er jo heldigvis en i sandhed uhyre rejse (Kafka 2008a: 292).

Hvad angår litteraturen, så har den aldrig lignet sig selv efter Kafka. Den stadige forhaling og udsættelse, han sætter i spil, synes at udmatte eller udtømme mulighederne for at læse teksterne symbolsk eller metaforisk. Sådanne læsninger ville kræve, at litteratur blot var at forstå som en omsætning af virkelighed til fiktion, men det, Kafka viser os, er, at fiktionen har sin egen, sære virkelighed, og han overleverer læseren en litterær erfaring af uro, skrig og latter, åben over for det fjerneste fjerne. 


\section{Litteratur}

Arendt, Hannah (1958): The Human Condition, Chicago og London: Chicago University Press.

Bergson, Henri (1993): Latteren. Et essay om komikkens væsen, Kbh.: Rævens sorte bibliotek.

Blanchot, Maurice (1973): Le pas au-delà, Paris: Gallimard.

Burke, Kenneth (1969a): A Grammar of Motives, Berkley, Los Angeles og London.

Burke, Kenneth (1969b): A Rhetoric of Motives, Berkley, Los Angeles og London.

Burke, Kenneth (1978): “(Nonsymbolic) Motion/(Symbolic) Action”, in Critical Inquiry, Vol. 4, No. 4.

Deleuze, Gilles og Guattari, Félix (1982): Kafka-for en mindre litteratur, Aarhus: Sjakalen.

Hariman, Robert (1995): “A Boarder in One’s Own Home: Franz Kafka’s Parables of the Bureaucratic Style", in Political Style. The Artistry of Power, Chicago og London: The University of Chicago.

Kafka, Franz:Aphorismen, e-udgave: http://www.digbib.org/Franz_Kafka_1883/Aphorismen?k=B etrachtungen $+\%$ FCber + S\%FCnde $\% 2 \mathrm{C}+$ Leid $\% 2 \mathrm{C}+$ Hoffnung + und + den + wahren + Weg .

Kafka, Franz (2008a): Efterladte fortællinger, Kbh.: Gyldendal.

Kafka, Franz (2008b): Fortællinger, Kbh.: Gyldendal.

Kafka, Franz (1981): Processen, Kbh.: Gyldendal.

Kafka, Franz (1980): Slottet, Kbh.: Gyldendal.

Koelb, Clayton (1983): “Kafka's Rhetorical Moment”, in PMLA, vol. 98, no.1.

de Man, Paul (1988): "Semiologi og retorik", in Tekst og trope. Dekonstruktion i Amerika (red. Andersen, L.A. og Hauge, H.), Aarhus: Modtryk.

Nietzsche, Friedrich (1989): "Darstellung der antiken Rhetorik" (1872-73), in Gilman, S.L. (red): Friedrich Nietzsche on Rhetoric and Language, New York og Oxford: Oxford University Press.

Starobinski, Jean (1947): "Le rêve architecte (à propos des intérieurs de Franz Kafka)", in Lettres, 23, Genève. 